\title{
Zmiany znaczeń wyrazów - projekt zajęć $z$ wiedzy o historycznym rozwoju polszczyzny
}

\author{
|Aleksandra Deskur
Uniwersytet im. Adama Mickiewicza, Poznań
ORCID: 0000-0002-6541-3581
}

Zmiany znaczeń wyrazów to jeden z najciekawszych tematów historycznojęzykowych $\mathrm{w}$ programie studiów pierwszego stopnia. Jest uwzględniony w sylabusie przedmiotu i obejmuje zagadnienia obowiązujące studentów na egzaminie. Punktem wyjścia niniejszego artykułu był konspekt ćwiczeń przeprowadzonych w grupie, w której na co dzień nie prowadziłam zajęć ${ }^{1}$. Projektując zadania, nie mogłam zatem brać pod uwagę specyfiki grupy oraz sposobu pracy studentów. Spotkanie zostało zaplanowane w taki sposób, aby jego realizacja była możliwa zarówno w wypadku dużego, jak i niewielkiego zaangażowania i aktywności uczestników (z uwzględnieniem zagadnień do rozmowy prowadzonej w zależności od odpowiedzi udzielanych przez studentów oraz zadań angażujących wszystkich członków grupy).

Głównym celem ćwiczeń było zaznajomienie studentów z problematyką zmian znaczeń wyrazów $w$ perspektywie diachronicznej. Osiągnięcie tegoż powinno sprawić, że studenci będą wiedzieć, czym jest znaczenie i zmiana znaczenia wyrazów, wymienią typy zmian znaczeń wyrazów (z podaniem odpowiednich przykładów), wskażą w tekście i w słowniku wyrazy, które zmieniły swoje znaczenia, a także nazwą i scharakteryzują typ zmiany oraz zrozumieją/wyjaśnią zewnętrzne przyczyny tego procesu.

Istotną wskazówką w budowaniu dydaktycznego projektu spotkania była dla mnie książka Jerome’a Brunera. Wykorzystałam głównie jego koncepcję narracji w edukacji² ${ }^{2}$ starając się ułożyć plan zajęć tak, aby poszczególne

\footnotetext{
${ }^{1}$ Autorka jest doktorantką w Zakładzie Historii Języka Polskiego na Wydziale Filologii Polskiej i Klasycznej UAM w Poznaniu. Zajęcia zostały przeprowadzone jako element metodycznego kształcenia uczestników studiów III stopnia w ramach konwersatoriów „Praktyka i teoria kształcenia akademickiego". Były hospitowane przez promotora pracy doktorskiej, wykładowcę prowadzącego zajęcia w grupie studenckiej, doktorantki i doktorantów oraz specjalistkę z zakresu dydaktyki. Szerzej zob. Dydaktyczna szkoła doktorska, 2019.

2 „Narracja zawiera sekwencję zdarzeń. Sekwencja ta jest nośnikiem znaczenia” - pisał Bruner (2006, 170).
} 
części wynikały z poprzednich i tworzyły spójną całość. Jednocześnie zależało mi na tym, by wyraźnie odrębne były poszczególne etapy tworzące sekwencję, poświęcone różnym zagadnieniom szczegółowym.

Ponieważ grupa aktywnie brała udział w pierwszym z zaproponowanych przeze mnie ćwiczeń, kolejne fazy zajęć rozpoczynały się właśnie od zadania, na podstawie którego przekazywałam merytoryczne informacje. W każdym przypadku działanie oparte na intuicji bądź wcześniejszej wiedzy potocznej/osobistej poprzedzało uzyskanie wiedzy naukowej/„właściwej", czyli związanej z tematem spotkania.

W kwestiach metodycznych czerpałam również z własnych obserwacji konwersatoriów prowadzonych przez pracowników Zakładu Historii Języka Polskiego UAM. Zdobyte w ten sposób doświadczenie praktyczne starałam się wykorzystywać przede wszystkim w aktywizacji studentów (konstruowanie zadań, zadawanie pytań, podsumowywanie i uzupełnianie udzielonych odpowiedzi, reagowanie na odpowiedzi błędne lub nieadekwatne do pytania, podsumowywanie zajęć).

\section{WSTĘP: CO TO JEST ZNACZENIE?}

Pierwsza część spotkania miała charakter przede wszystkim wykładowy - służyła zapoznaniu studentów z podstawowym nazewnictwem potrzebnym do dalszej pracy. Objaśnione zostały następujące terminy:

- znaczenie,

- desygnat,

- pojęcie,

- kategoria pojęciowa,

- zmiana znaczenia,

- prototyp.

Po krótkim wprowadzeniu przeszliśmy do części wymagającej działania studentów. W celu sprawdzenia, na ile grupa jest aktywna i czy będzie uczestniczyć w zajęciach, zaproponowałam krótkie ćwiczenie wstępne. Zadałam pytanie: co to jest ptak? - które następnie zostało doprecyzowane: jakie cechy musi mieć obiekt z rzeczywistości pozajęzykowej, abyśmy mogli nazwać go ptakiem? Na etapie udzielania odpowiedzi byłam w stanie ocenić zaangażowanie grupy jako zadowalające. Zgodnie z moimi oczekiwaniami studenci udzielali takich odpowiedzi, jak: ma skrzydła, lata, ma pióra etc. Wszystkie propozycje zapisywałam na tablicy w postaci prostego schematu: w jego centrum znalazł się omawiany wyraz, wokół którego pojawiły się wymienione przez uczestników zajęć cechy. Bardzo szybko zaczęto też weryfikować wcześniejsze wypowiedzi (np. stwierdzając, że nie każdy ptak lata, choć cecha ta została wcześniej wymieniona jako charakterystyczna). Jedna ze studentek zauważyła, że myśląc o ptaku, często wyobrażamy sobie jakiś konkretny gatunek, np. wróbla. To stwierdzenie umożliwiło po pierwsze pokazanie, czym „w praktyce” jest prototyp (centrum

Polonistyka. Innowacje

Numer 11, 2020 
danej kategorii pojęciowej, najbardziej typowy „egzemplarz” wśród desygnatów), po drugie - ukierunkowało naszą dalszą rozmowę, rozpoczynającą się od uświadomienia, że:

- znaczenie trudno uznać za stałą, niezmienną „zawartość” określonego wyrazu, może ono być zmienne $\mathrm{np}$. w zależności od uwarunkowań kulturowych;

- znaczenie nie jest jednorodne, stanowi wiązkę komponentów znaczących (semów) przypisywanych danemu desygnatowi; niektóre $\mathrm{z}$ nich są niezbędne, aby zidentyfikować dany desygnat, inne - możemy uznać za typowe, nie są one jednak konieczne, by zaliczyć jakiś obiekt do danej kategorii - w tym wypadku ptaków.

Powyższe założenia zostały sformułowane przeze mnie na podstawie wcześniejszych wypowiedzi studentów. Następnie podałam definicję znaczenia, którą posługiwaliśmy się podczas zajęć (zaznaczając jednocześnie, że w literaturze przedmiotu takich definicji jest bardzo dużo; m.in. Danuta Buttler w książce na temat zmian znaczeń wyrazów przywołuje dwie: relacyjną i konotacyjną): znaczenie to kompleks powiązanych ze sobą logicznie komponentów znaczących (semów) ${ }^{3}$.

Po krótkiej części wykładowo-objaśniającej przeszliśmy do kolejnego zadania, którego budowa była analogiczna do pierwszego. Tym razem pytanie brzmiało: co to jest krzesło? Studenci wymieniali cechy, które ma krzesło, a których nie mają inne meble (nogi, siedzisko, oparcie, etc.). Również w tym wypadku odpowiedzi posłużyły do stworzenia na tablicy prostego schematu złożonego z omawianego wyrazu (umiejscowionego w centrum) oraz jego cech i wysnucia wniosku, że istnieje pewna grupa cech, która decyduje o tym, że dany desygnat: 1) jest tym, czym jest; 2) odróżnia się od innych desygnatów (np. krzesło od fotela i taboretu) - wraz ze studentami wskazaliśmy te cechy na przykładzie krzesła. Studenci dowiedzieli się także, że poszczególne semy mogą ulegać zanikowi, wzmocnieniu, mogą także przesuwać się na pozycję centralną; do znaczenia mogą również dołączać nowe semy. Każdy taki „ruch” powoduje zmianę znaczenia. Ćwiczenie to służyło:

- utrwaleniu przyjętej definicji znaczenia jako wiązki elementów znaczących;

- stworzeniu punktu wyjścia do właściwych rozważań o zmianach znaczeń wyrazów.

Ten etap spotkania zajął ok. 20 minut.

\section{TYPY ZMIAN ZNACZEŃ WYRAZÓW}

Po części wprowadzającej przeszliśmy do głównego tematu, czyli zmian znaczeń wyrazów. Ta faza również rozpoczęła się od ćwiczenia, przy

\footnotetext{
${ }^{3}$ Zob. także Grzegorczykowa 2010, 17-19.
} 
realizacji którego oczekiwałam, że studenci będą sięgać do informacji przekazanych przeze mnie na początku zajęć oraz wiedzy z lektury (Kurkowska, 1949), choć nie wykluczałam również, że będą kierować się wiedzą ogólną.

Uczestnicy zostali podzieleni na kilka grup liczących po dwie-trzy osoby. Każda z grup otrzymała hasła słownikowe zaczerpnięte z słowników rejestrujących stan języka polskiego na różnych etapach rozwoju (Wielki słownik języka polskiego - WSJP, słownik Lindego - SL, Słownik staropolski - SStp). Każdy wyraz był reprezentowany przez dwa hasła słownikowe (dawne i współczesne). Podane zostały następujące przykłady:

błąd

SL: 'błąkanie, błąkanina, błądzenie, chybienie, uchybienie, myłka, omyłka (...) fizyczne lub moralne od prawdy, rzeczywistości, właściwości oddalenie się (...) W ogólności błąd, omyłka, omylenie co do rozumienia, lub postępowania (...) Omylne mniemanie i błąd'

WSJP: 1) 'coś, co jest niezgodne z obowiązującymi regułami w jakiejś dziedzinie nauki lub sztuki' 2) 'zachowanie lub postępowanie, które przyniosło niepożądane skutki'

błagać

SL: 'koić, śmierzyć, dobruchać, łagodzić prośbą'

WSJP: 'prosić o coś bardzo mocno i pokornie'

bolaczka

SL: 'wrzód bolący'

WSJP: 'niekorzystna sytuacja, stan lub sprawa odczuwane jako przyczyna zmartwień, dyskomfort bądź przeszkoda w życiu'

upokorzyć

SL: 'pokornie uniżyć'

WSJP: 'sprawić, że ktoś poczuł się poniżony'

ciąża

SL: 'brzemię, ciężar (...) dolegliwość, ucisk, ciężar (...) kara, karność (...) brzemienność, ciężarność, czas brzemienności'

WSJP: 'stan, w którym znajduje się kobieta lub samica innych ssaków od chwili zapłodnienia do urodzenia potomstwa'

przerazić

SStp: 'wedrzeć się gdzieś, wniknąć, przeniknąć, przebić na wylot'

WSJP: 'wywołać przerażenie'

jatka

SStp: 'budka kupiecka, kram, stragan'

WSJP: 1) 'zdarzenie, w którym ginie lub zostaje rannych wiele osób' 2) daw. 'sklep z mięsem' 3) 'w Polsce średniowiecznej: kram na placu targowym'

kobieta

SL: 'słowo w dawnych pismach rzadkie, (...) pierwiastkowo wzgardliwe, białogłowa, niewiasta'

WSJP: 1) 'dorosły człowiek płci żeńskiej’ 2) pot. 'żona lub kochanka’ 
stolec

SL: 'krzesło, np. królewskie, sądowe, tron, stolica (...) zwierzchność (...) stolec, zasada, fundament, podstawa (...) stolec, stołek dziurawy, z otworem w siedzeniu (...) Stolec do rodzenia (...) Stolec, naczynie potrzebne (sracz)'

WSJP: 1) 'substancja o przykrym zapachu, którą ludzie i zwierzęta wydalają jednorazowo z jelit przez odbyt' 2) przest. 'krzesło, na którym w oficjalnych sytuacjach zasiada monarcha, biskup lub inny dostojnik' 3) przest. 'władza królewska, książęca lub kościelna'

zabawa

SL: 'zabawa, bawienie, wstrzymywanie kogo w postępie czyli pośpiechu czynności, trudnienie i to co kogo trudni, wstrzymuje, bawi, zawada, zawód, przeszkoda (...) Zabawa, zatrudnienie, i to co zatrudnia, praca, robota, (...) Zabawa miła, przyjemna, którą czas miło się skraca (...) Zabawy dziecinne, igraszki, gry'

WSJP: 1) 'ogół czynności, w których wykonywanie ktoś angażuje się po to, żeby przyjemnie spędzić czas' 2) 'zorganizowane przedsięwzięcie artystyczne, sportowe lub rozrywkowe mające przyciągnąć wielu uczestników' 3) 'spotkanie towarzyskie, w czasie którego głównie się tańczy'

dziedzina

SL: 'wieś, majętność, grunt'

WSJP: 1) 'wydzielony zakres jakiejś ludzkiej aktywności' 2) książk. 'ziemia będąca czyjąś własnością'

gęba

SL: 'warga (...) W mnogich mówienia sposobach, słowa tego używamy, przez wzgląd na usta, albo jako na część twarzy, albo jako na narzędzie jedzenia, albo jako na narzędzie mowy'

WSJP: 1) pot. 'usta - otwór' 2) pot. 'twarz człowieka'

Poprosiłam studentów, aby zastanowili się, jak zmieniło się znaczenie różnych wyrazów, a następnie scharakteryzowali zmianę. Ćwiczenie to miało dwie części: pierwsza, trwająca około 15 minut, polegała na samodzielnej pracy w grupach. Podczas części drugiej uczestnicy zajęć prezentowali wylosowane przez siebie przykłady, mówili, jakie znaczenie miał dany wyraz dawniej, a jakie ma dziś, oraz opisywali, na czym polega modyfikacja znaczenia. Odpowiedzi studentów były zapisywane na tablicy. Następnie poprosiłam, aby powstały zbiór uporządkować według określonego klucza (np. posiłkując się przeczytanym wcześniej tekstem Kurkowskiej). Kryteria mieli zaproponować sami studenci. Oczekiwałam, że stworzony podział będzie miał charakter ogólny i będzie obejmował: rozszerzenie znaczenia, zawężenie, przeniesienie, zmianę nacechowania emocjonalnego (klasyfikacja, którą posługuje się Danuta Buttler"). Poniżej dla każdego typu podaję wybrane przykłady spośród analizowanych przez studentów.

- Rozszerzenie znaczenia (generalizacja): jeden z semów ulega zatarciu, w wyniku czego wyraz zaczyna się odnosić do większej liczby desygnatów, np. dziedzina.

\footnotetext{
${ }^{4}$ Buttler 1978, 48-166.
} 
- Zawężenie znaczenia (specjalizacja): jeden z semów ulega wzmocnieniu, w wyniku czego wyraz zaczyna się odnosić do mniejszej liczby desygnatów; może nastąpić np. w wyniku różnicowania dubletów (wyrazów synonimicznych), z których każdy zaczyna odnosić się do innego desygnatu, zatem oba synonimy zawężają swoje znaczenie (i przestają być synonimami); specjalizacja może być nieznaczna albo radykalna, przykłady: cią̇a, zabawa.

- Przeniesienie znaczenia: „przesunięcie dominanty (centrum) znaczenia wyrazu" (Butler 1978, 87); w przypadku tego typu kluczowa jest zmiana od znaczenia konkretnego do abstrakcyjnego (przeniesienie często ma charakter metaforyczny, gdyż tak postrzegamy rzeczywistość; zależało mi, aby ten konkretny podtyp przeniesienia znaczenia został przez studentów zapamiętany); przykłady: bolaczka, przerazić, błagać.

- Zmiana wartościowania danego wyrazu nacechowania emocjonalnego (melioracja i degradacja znaczenia): wyraz odnosi się do tego samego desygnatu, zmienia się jedynie jego wartościowanie - np. wyraz neutralny może stać się wyrazem wulgarnym lub nacechowanym negatywnie, przykłady: kobieta (melioracja, przy czym tu mamy do czynienia ze zmianą znaczenia z negatywnie nacechowanego do neutralnego; melioracja nie zawsze jest przesunięciem wyrazu do rejestru wysokiego), gęba (degradacja).

Przy analizie zmiany znaczenia skorzystałam ze schematu „kwiatków semantycznych", używanego na zajęciach z wiedzy o historycznym rozwoju polszczyzny. W środku „kwiatka” znajduje się znaczenie centralne, a „płatkami" są znaczenia poboczne, które mogą się odrywać. Zaczynają wtedy funkcjonować jako nowe znaczenia centralne, generujące nowe znaczenia poboczne. Nawiązałam też do części wstępnej naszych zajęć, podczas której rozmawialiśmy o koncepcji znaczenia jako wiązki elementów znaczących.

Warto zauważyć, że podział Kurkowskiej jest trochę inny: badaczka skupia się na konkretnych zmianach, które można uznać za reprezentatywne dla ogólniejszych typów. Założyłam, że jeżeli studenci pójdą podobnym tropem, podziału ogólnego dokonamy wspólnie (w drodze moderowanej i ewentualnie uzupełnianej przeze mnie rozmowy). Okazało się, że podział studentów tylko w niewielkim stopniu odbiegał od mojego „głównego" oczekiwania: wśród odpowiedzi pojawiło się zawężenie, rozszerzenie, zmiana nacechowania emocjonalnego, a także zmiana, którą studenci intuicyjnie rozumieli jako całkowitą czy głęboką (chodziło o przeniesienie znaczenia). Pojawiły się także głosy, że niektóre zmiany są związane z przejściem od znaczenia konkretnego do metaforycznego. Wskazany podział został przeze mnie uporządkowany, wprowadziłam także dodatkowe terminy (przeniesienie znaczenia, melioracja, degradacja) na określenie zjawisk, które wcześniej studenci opisywali własnymi słowami. 
Po zakończeniu ćwiczenia przekazałam studentom istotne informacje dotyczące zmian znaczeń wyrazów, dotyczące wszystkich typów zmian:

- zmiana znaczenia nie zawsze pociąga za sobą wycofanie się znaczenia pierwotnego; zdarza się, że wyrazy ze zmienionym znaczeniem funkcjonują jednocześnie $\mathrm{z}$ wyrazami o znaczeniu pierwotnym; Buttler pisze o zmianach całkowitych i niecałkowitych;

- zmiany znaczeń wyrazów nie zawsze mają charakter wyłączny, czasami można mówić o jednoczesnym zachodzeniu dwóch typów zmian (np. generalizacja i przeniesienie znaczenia, specjalizacja i degradacja);

- często jeden wyraz ulega więcej niż jednej zmianie; np. jatka: szałas, chata z gałęzi $\rightarrow$ kram, stragan (przeniesienie) $\rightarrow$ jatka mięsna (specjalizacja) $\rightarrow$ rzeź, masakra (przeniesienie na zasadzie metaforyzacji);

- zmiany znaczeniowe mogą mieć charakter "sprzężony”, jedna pociąga za sobą inne (np. żona, kobieta, niewiasta).

Po tej krótkiej części wykładowej zaplanowałam kolejne zadanie. Jest ono ważne i - jak sądzę - ciekawe, ponieważ pozwala studentom obserwować zmiany znaczenia wyrazów nie tylko na przykładzie danych słownikowych, ale również tekstów. Niestety nie starczyło nam na nie czasu i musiałam z niego zrezygnować. Alternatywny przebieg zajęć mógłby jednak wyglądać w ten sposób, by na jednych ćwiczeniach skupić się tylko na zmianach znaczeń wyrazów i charakterystyce ich typów (wówczas część ćwiczeniowa mogłaby być bardziej rozbudowana), a na następnych - przeanalizować wewnętrznojęzykowe i zewnętrznojęzykowe przyczyny zmian znaczeń wyrazów.

Studenci mieli otrzymać fragmenty tekstów staropolskich (krótkie, maksymalnie dwa-trzy zdania). Ich zadaniem było wyszukanie wyrazów, które zmieniły znaczenie i określenie, z jakim typem zmiany mamy do czynienia. Znaczenie pierwotne należało zrekonstruować na podstawie kontekstu (w razie potrzeby sięgnąć do Słownika staropolskiego), a następnie porównać ze znaczeniem współczesnym, podanym na podstawie własnej kompetencji językowej (choć i tu nie wykluczam sięgania np. do Wielkiego słownika języka polskiego). Ćwiczenie to miałoby na celu utrwalić zdobyte do tej pory informacje oraz wykształcić umiejętność ich praktycznego zastosowania. Przykładowe fragmenty tekstów (pogrubioną czcionką zaznaczono wyrazy, które należałoby przeanalizować):

O tem, jako syn boży zstąpił w żywot błogosławionej dziewice i o poczęciu jego w żywocie dziewice Maryje et cetera (Rozmyślanie przemyskie).

$\mathrm{K}$ temu słowu natychmiast dziwka wstała $a$ weselęcy sie urozumiała, iże jest przez Jesukrysta uzdrowiona i wkrzeszona. Wtenczas ta istna dziwka miała sobie dwanacie lecie, kiedy wkrzeszona s martwych (Rozmyślanie przemyskie). 
Wszakociesmy powiedzieli, iżeć zapowieda cesarzowi dań dawać, odwraca nasz zakon i nasz lud, krolem sie czyni, świętych dni nie dba, z dyjabłem dzierży a jego mocą, czusz dyjabelską, złe duchy wypędza, nowe nauki składa i ine rozmaite złe uczynki czyni. Abyć nie był złodziej, azabychmy ji podali tobie? (Rozmyślanie przemyskie).

Błogosławiony mąż, jen jest nie szedł po radzie niemiłościwych i na drodze grzesznych nie stał jest, i na stolcu nagłego spadnienia nie siedział jest, ale w zakonie bożem wola jego i w zakonie jego będzie myślić we dnie i w nocy (Psałterz floriański).

Tegodla, miły Gospodnie, piać będę chwałę Tobie i będę powyszać święte imię Twoje (Rozmyślanie przemyskie).

\section{PRZYCZYNY ZMIAN ZNACZEŃ WYRAZÓW}

Trzecia część zajęć miała charakter rozmowy odwołującej się do dotychczas omówionych problemów. Studenci mieli za zadanie wskazać najważniejsze przyczyny zmian znaczeń wyrazów (m.in. na podstawie przeczytanego tekstu Kurkowskiej). Poprosiłam również, aby omawiane przyczyny w miarę możliwości uzupełniać wcześniej analizowanymi przykładami (lub przykładami zaczerpniętymi z artykułu Kurkowskiej). Wymieniono:

- zmiany zachodzące w rzeczywistości pozajęzykowej;

- konieczność nazwania nieograniczonej sfery realiów pozajęzykowych za pomocą ograniczonego zasobu leksykalnego.

Ze względu na ograniczenia czasowe ta część zajęć musiała zostać zredukowana do przyczyn zewnętrznojęzykowych (z pominięciem wewnętrznojęzykowych). Jak pisałam wyżej, alternatywą mogłoby być poświęcenie przyczynom zmian znaczeń całych osobnych zajęć. Umożliwiłoby to również wprowadzenie na tym etapie ćwiczeń opartych na tekstach lub danych słownikowych.

\section{ZAKOŃCZENIE}

W jego ramach poprosiłam studentów, aby sami wskazali, co ich zdaniem jest najważniejsze do zapamiętania z zakresu omawianego tematu. Pozwoliło to zaktywizować studentów do samodzielnego syntetyzowania i hierarchizowania zdobytych wiadomości, a jednocześnie było informacją zwrotną dla mnie - mogłam w ten sposób ustalić, na ile udało mi się zrealizować założone cele zajęć. Studenci wskazali następujące zagadnienia:

- świadomość tego, czym jest znaczenie (wiązką elementów znaczących);

- wyróżnienie typów zmian znaczenia (rozszerzenie, zawężenie, przeniesienie, zmiana nacechowania emocjonalnego);

- metaforyzacja jako bardzo ważny podtyp przeniesienia znaczenia;

- kilkakrotne zmiany znaczenia tego samego wyrazu, różne typy zmiany znaczenia, które mogą zachodzić równocześnie. 
Po wyborze istotnych dla studentów zagadnień poprosiłam o dokonanie ich hierarchizacji (powyższy wykaz ją odzwierciedla). W podsumowaniu znalazły się wszystkie kwestie, których zapamiętania i rozumienia oczekiwałam od studentów.

Największym wyzwaniem $\mathrm{w}$ prowadzeniu ćwiczeń $\mathrm{z}$ wiedzy o historycznym rozwoju polszczyzny jest dla mnie aktywizacja studentów. Nie wszystkie grupy równie chętnie biorą udział w rozmowie, z kolei nie każdy temat da się przeprowadzić w sposób „warsztatowy”, polegający na wykonywaniu określonych zadań. Zmiany znaczeń wyrazów to zagadnienie, które na ogół wzbudza zainteresowanie studentów, chętnie włączają się oni nie tylko w proponowane przeze mnie zadania, ale również w rozmowę. Podobnie było $\mathrm{w}$ wypadku zajęć, na podstawie których powstał powyższy artykuł: uczestnicy brali udział w ćwiczeniach i odpowiadali na pytania, ale też sami proponowali ciekawe rozwiązania, prosili o doprecyzowanie niektórych kwestii. Wydaje mi się, że sprzyjała temu przyjęta przeze mnie kolejność: najpierw należało wykonać zadanie praktyczne, a dopiero na jego podstawie wprowadzałam wiedzę merytoryczną. Mechanizm ten był dla mnie szczególnie istotny w wypadku głównego zadania, polegającego na scharakteryzowaniu zmiany znaczenia, która zaszła w podanym przykładzie, oraz samodzielnym sformułowaniu uogólnień. Studenci poradzili sobie z tym zadaniem bardzo dobrze, ponadto wydaje mi się, że zdobyta wiedza i umiejętności się utrwaliły (a przynajmniej na to wskazywało podsumowanie). Potwierdziło to wniosek Manfreda Spitzera dotyczący skutecznego sposobu uczenia się, zgodnie z którym efektywne poznawanie wymaga formułowania ogólnych zasad na podstawie przetworzonych przykładów (por. Spitzer 2011, 66-68).

\section{Bibliografia}

\section{Lektura wstępna dla studentów:}

Kurkowska Halina, 1949, O zmianach znaczeń wyrazów, „Poradnik Językowy”, z. 3.

\section{Literatura wykorzystana przez prowadzącą:}

Buttler Danuta, 1978, Rozwój semantyczny wyrazów polskich, Warszawa.

Grzegorczykowa Renata, 2010, Wprowadzenie do semantyki językoznawczej, Warszawa.

Kleszczowa Krystyna, 2012, Tajemnice dynamiki języka. Księga jubileuszowa, Katowice.

Korpus tekstów staropolskich, https://ijp.pan.pl/publikacje-i-materialy/zasoby/ korpus-tekstow-staropolskich/ [dostęp: 19.08.2019].

Kurkowska Halina, 1949, O zmianach znaczeń wyrazów, „Poradnik Językowy”, z. 3.

Linde Samuel Bogumił, 1807-1814, Słownik języka polskiego, Warszawa, http://kpbc.umk.pl/dlibra/publication?id=8173\&tab=3 [dostęp: 19.08.2019] (SL). 
Słownik staropolski, 1953, Warszawa-Kraków (SStp).

Wielki słownik języka polskiego, Żmigrodzki P. (red.), https://www.wsjp.pl/ [dostęp: 19.08.2019] (WSJP).

\section{Literatura z zakresu metodyki:}

Bruner Jerome, 2006, Kultura edukacji, Brzostowska-Tereszkiewicz T. (przeł.), Kraków.

Dydaktyczna szkoła doktorska, 2019, Kwiatkowska-Ratajczak M. (red.), Poznań.

Spitzer Manfred, 2007, Jak uczy się mózg, Guzowska-Dąbrowska M. (przeł.), Warszawa. 